\title{
ANTIHYPERTENSIVE EFFECT OF THE PUNICA GRANATUM JUICE IN DEOXYCORTICOSTERONE ACETATE-SALT MODEL OF HYPERTENSION IN RATS
}

\author{
CHAUDHARI PANKAJ M*, BAVISKAR DHEERAJ T, MAHAJAN SACHIN N
}

Department of Pharmacology, Kisan Vidya Prasarak Sanstha's, Institute of Pharmaceutical Education, Boradi, Shirpur, Dhule - 425 428, Maharashtra, India. Email: daal15@rediffmail.com

Received: 25 January 2018, Revised and March: 21 March 2018

\section{ABSTRACT}

Objective: Hypertension an important global health challenge is the prevalent cause of cardiovascular disease. Natural products are emerging as new therapeutic tools in the management of hypertension due to side effects and the patient's adherence of the existing treatments. In the present study, we investigated the antihypertensive effect of the Punica granatum juice in deoxycorticosterone acetate (DOCA)-salt model of hypertension in rats.

Methods: Antihypertensive activity was evaluated in P. granatum juice extract (PGJ) (PJ-100 mg/kg and $300 \mathrm{mg} / \mathrm{kg}$; p.o.) for 4 weeks in DOCA treated rats. Blood pressure by non-invasive (indirect) method and invasive method was measured. Further, vascular reactivity to noradrenaline $(1 \mu \mathrm{g} / \mathrm{kg})$, adrenaline $(1 \mu \mathrm{g} / \mathrm{kg})$, phenylephrine $(1 \mu \mathrm{g} / \mathrm{kg})$, serotonin $(1 \mu \mathrm{g} / \mathrm{kg})$, and angiotensin II $(25 \mathrm{ng} / \mathrm{kg})$ was recorded. Antioxidant studies such as thiobarbituric acid reactive substances (TBARS); while enzyme activity of superoxide dismutase (SOD), catalase (CAT), and glutathione reductase (GSH) in kidney tissue was also carried out.

Results: Administration of PGJ (PJ-100 mg/kg and $300 \mathrm{mg} / \mathrm{kg}$; p.o.) for 4 weeks in DOCA treated rats significantly ( $<0.05)$ reduced the mean arterial blood pressure and vascular reactivity changes to various catecholamines. PJ treatment significantly $(\mathrm{p}<0.05)$ decreased the levels of TBARS; while enzyme activity of SOD, CAT, and GSH in kidney tissue was significantly increased.

Conclusion: Results of the present work suggest that PGJ has an antihypertensive action in unilateral nephrectomized DOCA-salt hypertensive rats and could be possible starting point for treatment of hypertension with increased patient adherence.

Keywords: Punica granatum juice, Deoxycorticosterone acetate-salt model of hypertension, Oxidative stress, Patient's adherence.

(C) 2018 The Authors. Published by Innovare Academic Sciences Pvt Ltd. This is an open access article under the CC BY license (http://creativecommons. org/licenses/by/4. 0/) DOI: http://dx.doi.org/10.22159/ajpcr.2018.v11i6.24950

\section{INTRODUCTION}

Blood pressure is the force of blood against your artery walls as it circulates through your body. Hypertension an important global health challenge is the prevalent cause of the cardiovascular disease that leads to heart failure, stroke, renal failure, and ultimately death. [1].

One of the main problems related to the management of hypertension due to side effects related to the treatment is the adherence to the treatment, which is estimated as $57 \%$ of the patients [2,3]. Therefore, natural products from plants used in traditional medicine may serve as important information for future drug discovery and development efforts in the area.

Of such traditional importance is the pomegranate, Punica granatum L., a highly distinctive fruit which is used in variety of ailment since ages, is the predominant member of two species comprising the Punicaceae family. In Ayurvedic medicine it is used as an antiparasitic agent, a "blood tonic," and to heal aphthae, diarrhea, and ulcers. Pomegranate also serves as a remedy for diabetes in the Unani system of medicine practiced in the Middle East and India. The current explosion of interest in pomegranate as a medicinal and nutritional product is evidenced by a many scientific reports. The potential therapeutic properties of pomegranate are wide-ranging and include treatment and prevention of cancer, cardiovascular disease, diabetes, dental conditions, erectile dysfunction, and protection from ultraviolet radiation. Other potential applications include infant brain ischemia, Alzheimer's disease, male infertility, arthritis, and obesity [4,5].

The present study aimed at investigating the antihypertensive effect of the P. granatum and their respective mechanisms of action in deoxycorticosterone acetate (DOCA)-salt model of hypertension in rats as DOCA-salt hypertensive rats, provides a reliable animal model of oxidative and inflammatory stress in the cardiovascular system.

\section{METHODS}

\section{Animals}

Female albino rats (Wistar strain) weighing between 150 and $200 \mathrm{~g}$ were obtained from Serum Institute, Pune. Animals were housed into groups of five under standard laboratory conditions of temperature $25^{\circ} \mathrm{C} \pm 1^{\circ} \mathrm{C}$ with free access to food (Hindustan Lever, India) and water. The experiments were performed during the light portion (9-14 h). The experiments were carried out according to the guidelines of the Committee for the Purpose of Control and Supervision of Experiments on Animals, New Delhi, India, and approved by the Institutional Animal Ethical Committee.

\section{Drugs and chemicals}

Adrenaline (Adr), noradrenaline (NA), phenylephrine (PE), serotonin (5-HT), angiotensin (AngII), urethane, and DOCA were purchased from Sigma-Aldrich, Mumbai. All drug solutions were freshly prepared in saline before each experiment.

\section{Plant material}

P. granatum fruits $(1 \mathrm{~kg})$ were obtained locally and were authenticated by Dr. D. A. Patil (SSVPS, Science College, Dhule). $1 \mathrm{~kg}$ of pomegranate fruits was purchased from local market. The seeds were isolated and were ground to obtain juice. The juice was air dried and concentrated under reduced pressure to obtain $35 \mathrm{~g}$. An appropriate concentration of the extracts was made in distilled water for studying antihypertensive effect. 


\section{Induction of DOCA salt-hypertension}

Animals were anesthetized by ketamin $(75 \mathrm{mg} / \mathrm{kg}$; i.p) and xylazine (7.5 mg/kg; i.p). Hypertensive group underwent uninephrectomy through the left flank incision. Then, the wounds were closed with silk suture (Ethicon). All operated rats received an injection of ampicillin $(10 \mathrm{mg} / \mathrm{kg}$, i.m.) daily for 5 days. Neosporin powder (polymyxin B sulfate BP, Zinc bacitracin BP, and neomycin sulfate IP) was applied locally to prevent infection. A week after unilateral nephrectomy, DOCA (25 mg/kg, once a week; s.c; for 4 weeks) dispersed in cottonseed oil was injected to uninephrectomized rats. $1 \%$ saline and $0.2 \% \mathrm{KCl}$ ad libitum were given throughout the experiment instead of drinking water [6].

\section{Experimental protocol for $P$. granatum}

The unilateral nephrectomized female rats were divided into 6 groups of 5 rats each

Group I: Sham control, unilateral nephrectomized animals receive daily injection of $0.1 \mathrm{ml}$ of sterilized cottonseed oil subcutaneously for 4 weeks and $0.2 \% \mathrm{KCl}$ ad libitum as drinking water.

Group II: Unilateral nephrectomized animals receive $P$. granatum $(100 \mathrm{mg} / \mathrm{kg} /$ day) for 4 weeks and $1 \%$ saline and $0.2 \% \mathrm{KCl}$ ad libitum as drinking water

Group III: Unilateral nephrectomized animals receive $P$. granatum (300 mg $/ \mathrm{kg} /$ day) for 4 weeks and $1 \%$ saline and $0.2 \% \mathrm{KCl}$ ad libitum as drinking water

Group IV: Unilateral nephrectomized animals receive DOCA injection (25 mg/kg/week, s.c.) for 4 weeks, dissolved in sterilized cottonseed oil subcutaneously and $1 \%$ saline and $0.2 \% \mathrm{KCl}$ ad libitum as drinking water

Group V: Unilateral nephrectomized animals receive DOCA injection $(25 \mathrm{mg} / \mathrm{kg} /$ week, s.c.), P. granatum $(100 \mathrm{mg} / \mathrm{kg} /$ day, p.o.) for 4 weeks and $1 \%$ saline and $0.2 \% \mathrm{KCl}$ ad libitum as drinking water.

Group VI: Unilateral nephrectomized animals receive DOCA injection (25 mg/kg/week, s.c.), P. granatum (300 mg/kg/day, p.o.) for 4 weeks and $1 \%$ saline and $0.2 \% \mathrm{KCl}$ ad libitum as drinking water

\section{Measurement of blood pressure [7]}

Measurement of blood pressure by non-invasive (indirect) method The rats were trained for at least 1 week until the BP is steadily recorded with minimal stress and restrain. The first cardiovascular parameters were discarded and mean of five or six subsequent measurements were recorded. Systolic blood pressure is measured weekly for 4 weeks by an indirect non-invasive tail-cuff method using power lab.

\section{Measurement of blood pressure by invasive (direct) method}

After completion of treatment schedule rats from each group were anesthetized with urethane $(120 \mathrm{mg} / 100 \mathrm{~g})$. Femoral vein is cannulated with fine polyethylene catheter for administration of the drug. Tracheostomy is performed, and blood pressure is recorded from left common carotid artery using pressure transducer by a direct method on chart data system. Heparinized saline $(100 \mathrm{IU} / \mathrm{ml})$ is filled in the transducer and in the fine polyethylene catheter cannulated to the carotid artery to prevent clotting. After $30 \mathrm{~min}$ of stabilization, heart rate, basal blood pressure, and vascular reactivity to NA (1 $\mu \mathrm{g} / \mathrm{kg})$, Adr $(1 \mu \mathrm{g} / \mathrm{kg})$, PE $(1 \mu \mathrm{g} / \mathrm{kg}), 5-\mathrm{HT}(1 \mu \mathrm{g} / \mathrm{kg})$, and Ang II (25 ng/kg) were recorded.

\section{Antioxidant studies}

After completion of treatment schedule, the heart of rat from the individual group was dissected out, immediately washed in icecold saline and weighed. $10 \%$ homogenate was prepared in $0.1 \mathrm{M}$
Tris-buffer, $\mathrm{pH}$ 7.4. The homogenate was centrifuged at $15,000 \times \mathrm{g}$ for $20 \mathrm{~min}$. The supernatants were used for measuring activity of antioxidant enzymes: Superoxide dismutase (SOD), catalase (CAT), reduced glutathione (GSH), and thiobarbituric acid reactive substances (TBARS).

\section{Determination of enzymic antioxidant status}

\section{SOD activity}

The assay of SOD was based on the ability of SOD to inhibit spontaneous oxidation of Adr to adrenochrome [8,9]. To $0.05 \mathrm{ml}$ supernatant, $2.0 \mathrm{ml}$ of carbonate buffer, and $0.5 \mathrm{ml}$ of EDTA were added. The reaction was initiated by addition of $0.5 \mathrm{ml}$ of epinephrine, and the auto-oxidation of $\mathrm{Adr}\left(3 \times 10^{-4} \mathrm{M}\right)$ to adrenochrome at $\mathrm{pH} 10.2$ was measured by following the change in OD at $480 \mathrm{~nm}$. The change in optical density every minute was measured at $480 \mathrm{~nm}$ against reagent blank. The results are expressed as units of SOD activity (U/g wet tissue). One unit of SOD activity induced approximately 50\% inhibition of Adr.

\section{CAT activity}

The CAT activity assay was based on the ability of CAT to induce the disappearance of hydrogen peroxide [10]. The reaction mixture consisted of $2 \mathrm{ml}$ phosphate buffer ( $\mathrm{pH} 7.0$ ), $0.95 \mathrm{ml}$ of hydrogen peroxide $(0.019 \mathrm{M})$ and $0.05 \mathrm{ml}$ supernatant in final volume of $3 \mathrm{ml}$. Absorbance was recorded at $240 \mathrm{~nm}$ every $10 \mathrm{~s}$ for $1 \mathrm{~min}$. One unit of CAT was defined, as the amount of enzyme required decomposing $1 \mu \mathrm{mol}$ of peroxide per min, at $25^{\circ} \mathrm{C}$ and $\mathrm{pH}$ 7.0. The results were expressed as units of CAT activity (U/g wet tissue)

\section{Estimation of reduced glutathione}

Reduced glutathione was determined by the method of Ellman [11], $1.0 \mathrm{ml}$ of homogenate was added to $1 \mathrm{ml}$ of $10 \%$ TCA and centrifuged. $1.0 \mathrm{ml}$ of supernatant was treated with $0.5 \mathrm{ml}$ of Ellman's reagent (19.8 mg of 5, 5'-dithiobisnitro benzoic acid in $100 \mathrm{ml}$ of $1.0 \%$ sodium citrate) and $3 \mathrm{ml}$ of phosphate buffer ( $\mathrm{pH} \mathrm{8.0)}$. The color developed was measured at $412 \mathrm{~nm}$

\section{Estimation of lipid peroxidative indices}

Lipid peroxidation as evidenced by the formation of TBARS was measured by the method of Niehaus and Samuelsson [12]. $0.1 \mathrm{ml}$ of homogenate (Tris-HCL buffer, $\mathrm{pH} 7.5$ ) was treated with $2 \mathrm{ml}$ of (1:1:1 ratio) TBA-TCA-HCl reagent (Thiobarbituric acid $0.37 \%, 0.25 \mathrm{~N}$ $\mathrm{HCl}$, and 15\% TCA) and placed in water bath for $15 \mathrm{~min}$, cooled and centrifuged at room temperature for $10 \mathrm{~min}$ at $1000 \mathrm{rpm}$. The absorbance of the clear supernatant was measured against reference blank at $535 \mathrm{~nm}$.

\section{Urinary electrolyte excretion studies}

Rats were kept in metabolic cages for $24 \mathrm{~h}$. Urine is collected under mineral oil to avoid evaporation. Urinary sodium and potassium excretion $(\mathrm{mMol} / \mathrm{ml})$ are calculated from urine samples collected from rats kept in metabolic cages for $24 \mathrm{~h}$ at the end of the I, II, III and IV weeks by Flame Photometry (Model Toshniwal Instruments, Mumbai) [13].

\section{Statistical analysis}

The mean \pm standard error of mean values was calculated for each group using GraphPad Prism 5.0. One-way ANOVA followed by Dunnett's multiple comparison tests were used for statistical analysis. $\mathrm{p}<0.05$ value was considered statistically significant.

\section{RESULTS}

Measurement of blood pressure by non-invasive (indirect) method Administration of DOCA for 4 weeks in unilateral nephrectomized rats produced a significant elevation $(\mathrm{p}<0.05)$ in systolic blood pressure (SBP) as measured by tail-cuff method on II, III, and IV weeks when compared to sham control rats. Unilateral nephrectomized rats which received P. granatum juice extract (PGJ) (100 and $300 \mathrm{mg} / \mathrm{kg} /$ day, p.o.) for 4 weeks along with DOCA significantly $(\mathrm{p}<0.05)$ reduced SBP on 
III and IV weeks as compared with SBP of unilateral nephrectomized DOCA-salt hypertensive rats, thus implying an antihypertensive effect. However, chronic administration of PGJ (100 and $300 \mathrm{mg} / \mathrm{kg} /$ day, p.o.) in unilateral nephrectomized rats for 4 weeks did not alter SBP as compared to sham control (Table 1 and Fig. 1).

\section{Measurement of blood pressure by invasive (direct) method}

The heart rate, basal arterial blood pressure, and pressor responses to NA, Adr, PE, 5-HT, and AngII were significantly $(\mathrm{p}<0.05)$ increased in unilateral nephrectomized DOCA-salt hypertensive rats as compared to sham control rats. The heart rate, basal arterial blood pressure, and pressor responses to NA, Adr, PE, 5-HT, and AngII were significantly $(p<0.05)$ reduced in case of unilateral nephrectomized DOCA-salt hypertensive rats that received PGJ (100 and $300 \mathrm{mg} / \mathrm{kg} /$ day, p.o.) for 4 weeks as compared to unilateral nephrectomized DOCA-salt hypertensive rats. The heart rate, basal arterial blood pressure, and pressor responses to NA, Adr, PE, 5-HT, and AngII were not altered in case of PGJ (100 and $300 \mathrm{mg} / \mathrm{kg} /$ day, p.o.) treated unilateral nephrectomized rats as compared to sham control rats (Tables 2 and 3).

\section{Antioxidant studies}

The antioxidant levels of SOD, CAT, GSH enzymes, and TBARS in sham control rats were found to be $159.2 \mathrm{U} / \mathrm{g}$ of wet tissue, $2.03 \mathrm{U} / \mathrm{g}$ of wet tissue, $40.59 \mathrm{nM} / \mathrm{mg}$ of wet tissue, and $4.91 \mathrm{nM} / \mathrm{mg}$ of wet tissue, respectively. The antioxidant levels SOD, CAT, GSH enzymes, and TBARS were not altered in case of PGJ (100 and $300 \mathrm{mg} / \mathrm{kg} /$ day, p.o.) treated unilateral nephrectomized rats as compared to sham control rats. The antioxidant levels of SOD, CAT, and GSH enzymes were significantly $(p<0.05)$ decreased and those of TBARS were significantly $(p<0.05)$ increased in heart tissue of unilateral nephrectomized DOCA-salt hypertensive rats when compared to sham control rats. The levels of antioxidant enzymes SOD, CAT, and GSH were significantly $(\mathrm{p}<0.05)$ increased and those of TBARS were significantly $(\mathrm{p}<0.05)$ decreased in heart tissue of unilateral nephrectomized DOCA-salt hypertensive rats that received PGJ (100 and $300 \mathrm{mg} / \mathrm{kg} /$ day, p.o.) for 4 weeks as compared to unilateral nephrectomized DOCA-salt hypertensive rats (Figs. 2-5 and Table 4).

\section{Urinary sodium $\left(\mathrm{K}^{+}\right)$excretion studies}

Administration of DOCA for 4 weeks in unilateral nephrectomized rats showed a significant $(\mathrm{p}<0.05)$ increase in $\mathrm{K}^{+}$excretion at the end of I and II weeks as compared to sham control rats. Unilateral nephrectomized rats which received PGJ (100 and $300 \mathrm{mg} / \mathrm{kg} /$ day, p.o.) for 4 weeks along with DOCA showed a significant $(\mathrm{p}<0.05)$ decrease in $\mathrm{K}^{+}$excretion as compared to DOCA group. However, chronic administration of PGJ (100 and $300 \mathrm{mg} / \mathrm{kg} /$ day, p.o.) for 4 weeks in unilateral nephrectomized rats showed a significant $(\mathrm{p}<0.05)$ decrease in $\mathrm{K}^{+}$excretion as compared to sham control rats (Table 5).

\section{DISCUSSION}

The prevention and management of hypertension are major public health challenge globally. A number of important causal factors for hypertension have been identified, including excess body weight; excess dietary sodium intake; reduced physical activity; inadequate intake of fruits, vegetables, and potassium; and excess alcohol intake. It is the leading risk factor for mortality claiming nearly 1.5 million lives each year in the region [14].

According to a survey, only $25 \%$ of the people taking modern treatment of hypertension are able to keep their arterial BP within normal range. The reasons for this are many, including the adverse effects of drugs and relatively high cost of treatment. Use of traditional medicine in the treatment of ailments focuses on affordability and the individualization of the treatment for hypertension and many of the cardiovascular diseases. Even though a large number of drugs are available for the treatment of hypertension, traditional medicine has served as starting points for new therapeutics as they are safe and affordable [15].

In the present study, we investigated the effect of PGJ on urinary electrolyte excretion, blood pressure, and oxidative stress in DOCA-saltinduced hypertensive rats.

Oxidative stress (OS) is intricately combined with inflammation elicits a chronic pathophysiological stress state, especially as seen in hypertension. The hypertension induced by DOCA is due to retention of sodium and water. It has been shown that the altered membrane permeability in the unilaterally nephrectomized DOCAsalt hypertensive models causes abnormal cation turnover [16]. This abnormal cation turnover leads to vasoconstriction and finally increased arterial blood pressure. The increased vascular sensitivity to catecholamines in DOCA-salt hypertensive rats is also due to increased mobilization of calcium ion into the vascular smooth muscle. It is possible that the alteration in voltage operative calcium channels or calcium permeability is the main reason for the maintenance of hypertension in the DOCA-salt hypertensive model [17]. DOCA causes hypokalemia which, in turn, blunts the biosynthesis of adrenal corticosteroids [18].

In the present study, it was observed that in unilateral nephrectomized DOCA-salt hypertensive rats showed a significant $(\mathrm{p}<0.05)$ decrease in $\mathrm{Na}^{+}$excretion at the end of II and III weeks and significant $(p<0.05)$ increase in $\mathrm{K}^{+}$excretion at the end of I and II weeks as compared to sham control rats. Chronic administration of PGJ (100 and $300 \mathrm{mg} / \mathrm{kg} /$ day, p.o., for 4 weeks) in unilateral nephrectomized rats did not significantly $(\mathrm{p}<0.05)$ altered $\mathrm{Na}^{+}$and $\mathrm{K}^{+}$excretion as compared to sham control rats. However, unilateral nephrectomized rats which received PGJ (100 and $300 \mathrm{mg} / \mathrm{kg} /$ day, p.o., for 4 weeks) treated DOCA-salt hypertensive rats showed a significant $(\mathrm{p}<0.05)$ increase in $\mathrm{Na}^{+}$excretion and significant $(\mathrm{p}<0.05)$ decrease in $\mathrm{K}^{+}$as compared to DOCA group. This suggests impairment of sodiumpotassium balance in DOCA-salt hypertensive rats. Administration of PGJ (100 and $300 \mathrm{mg} / \mathrm{kg} /$ day, p.o., for 4 weeks) in DOCA rats show a reversal in impairment of sodium-potassium balance as observed in DOCA animals. The subsequent development of hypertension was correlated with decreased fractional excretion of urinary sodium levels in DOCA group measured at the end of II and III weeks. This suggests that increased renal sympathetic tone in the DOCA-salt rat facilitates sodium retention and is necessary for the development of

Table 1: Effect of Punica granatum juice extract $(100,300 \mathrm{mg} / \mathrm{kg} / \mathrm{day}$, p.o., for 4 weeks) on SBP in DOCA-salt hypertensive rats

\begin{tabular}{llllll}
\hline \multirow{2}{*}{ Treatment groups (mg/kg) } & \multicolumn{2}{l}{ Mean SBP ( $\mathbf{m m}$ Hg) } & & \\
\cline { 2 - 6 } & 0 week & I week & II week & III week & IV week \\
\hline Sham control & $105.7 \pm 3.42$ & $111.7 \pm 2.21$ & $103.0 \pm 0.59$ & $112.0 \pm 3.42$ & $115.0 \pm 0.62$ \\
Punica granatum juice extract (100) & $105.0 \pm 1.85$ & $106.0 \pm 3.82$ & $106.5 \pm 2.57$ & $109.2 \pm 0.65$ & $113.0 \pm 0.95$ \\
Punica granatum juice extract (300) & $105.3 \pm 2.92$ & $109.4 \pm 1.21$ & $106.2 \pm 2.92$ & $107.0 \pm 1.54$ & $104.3 \pm 2.22^{*}$ \\
DOCA (25) & $104.3 \pm 3.72$ & $112.8 \pm 2.15$ & $128.8 \pm 2.95^{*}$ & $135.3 \pm 1.86^{*}$ & $145.2 \pm 0.58^{*}$ \\
DOCA (25)+Punica granatum juice extract (100) & $106.0 \pm 1.56$ & $106.8 \pm 3.72$ & $118.8 \pm 3.12$ & $125.2 \pm 3.56^{\#}$ & $118.8 \pm 0.67^{\#}$ \\
DOCA (25)+Punica granatum juice extract (300) & $105.0 \pm 3.41$ & $108.0 \pm 0.56$ & $111.3 \pm 0.54^{\#}$ & $112.1 \pm 3.78^{\#}$ & $108.0 \pm 1.57^{\#}$ \\
\hline
\end{tabular}

All values are expressed as mean \pm SEM, $n=5$. All data are subjected to one-way ANOVA followed by Dunnett's test. * $\mathrm{p}<0.05$ when compared to sham control and ${ }^{\#}<<0.05$ when compared to DOCA group. DOCA: Deoxycorticosterone acetate, SEM: Standard error of the mean, SBP: Systolic blood pressure 
hypertension. Treatment with PGJ (100 and $300 \mathrm{mg} / \mathrm{kg} /$ day, p.o., for 4 weeks) in DOCA-salt hypertensive rats did not facilitate sodium retention.

In the present study, we observed that unilateral nephrectomized DOCA rats produced a significant elevation $(\mathrm{p}<0.05)$ in SBP as measured by tail-cuff method on II, III, and IV weeks when compared to sham control rats. PGJ (100 and $300 \mathrm{mg} / \mathrm{kg} /$ day, p.o., for 4 weeks) treated unilateral nephrectomized animals did not exhibit any significant change in SBP. Administration of PGJ (100 and $300 \mathrm{mg} / \mathrm{kg} /$ day, p.o., for 4 weeks) in unilateral nephrectomized DOCA-salt hypertensive rats significantly

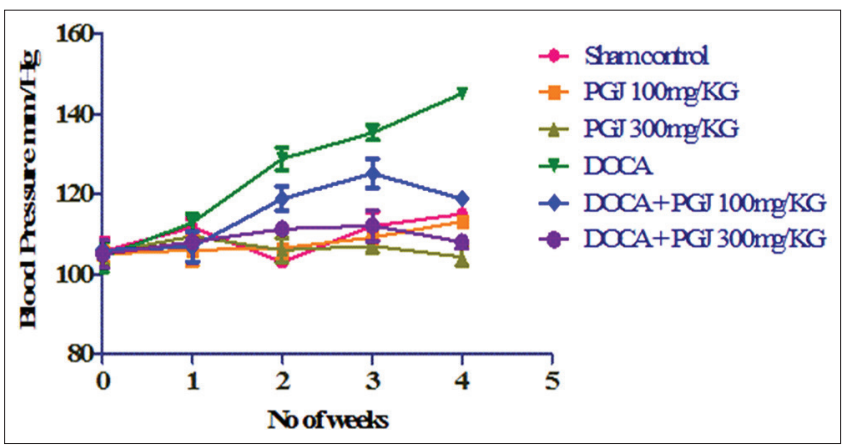

Fig. 1: Effect of PGJ (100 and $300 \mathrm{mg} / \mathrm{kg} /$ day, p.o., for 4 weeks) on systolic blood pressure in deoxycorticosterone acetate-salt hypertensive rats. Vertical lines represent SEM. All values are expressed as mean \pm SEM. $n=5$, all data are subjected to one-way ANOVA followed by Dunnett's test. * $\mathbf{p}<0.05$ when compared to sham control and \#p $<0.05$ when compared to DOCA group. PGJ: Punica granatum juice extract, DOCA: Deoxycorticosterone acetate, SEM: Standard error of the mean

Table 2: Effect of Punica granatum juice extract (100 and $300 \mathrm{mg} / \mathrm{kg} / \mathrm{day}$, p.o., for 4 weeks) on heart rate (BPM) and basal arterial blood pressure in DOCA-salt hypertensive rats

\begin{tabular}{lll}
\hline $\begin{array}{l}\text { Treatment } \\
\text { groups (mg/kg) }\end{array}$ & $\begin{array}{l}\text { Basal arterial blood } \\
\text { pressure (mm Hg) }\end{array}$ & $\begin{array}{l}\text { Heart } \\
\text { rate (BPM) }\end{array}$ \\
\hline $\begin{array}{l}\text { Sham control } \\
\text { Punica granatum juice }\end{array}$ & $95.63 \pm 4.74$ & $325 \pm 5.67$ \\
extract (100) & $90.0 \pm 4.04$ & $330 \pm 7.82$ \\
$\begin{array}{l}\text { Punica granatum juice } \\
\text { extract (300) }\end{array}$ & $99.5 \pm 0.50$ & $340 \pm 8.42$ \\
$\begin{array}{l}\text { DOCA (25) } \\
\text { DOCA+Punica granatum }\end{array}$ & $138 \pm 4.79^{*}$ & $428 \pm 12.58^{*}$ \\
juice extract (100) & $95.5 \pm 3.20^{\#}$ & $318 \pm 9.14^{\#}$ \\
$\begin{array}{l}\text { DOCA+Punica granatum } \\
\text { juice extract (300) }\end{array}$ & $99.3 \pm 2.51^{\#}$ & $343 \pm 7.42^{\#}$ \\
\hline
\end{tabular}

All values are expressed as mean \pm SEM, $n=5$. All data are subjected to one-way ANOVA followed by Dunnett's test. *p $<0.05$ when compared to sham control and ${ }^{\#} \mathrm{p}<0.05$ when compared to DOCA group. DOCA: Deoxycorticosterone acetate, SEM: Standard error of the mean $(\mathrm{p}<0.05)$ reduced the SBP as compared to unilateral nephrectomized DOCA group. Heart rate, basal arterial blood pressure, and pressor responses to NA, Adr, PE, 5-HT, and AngII were significantly $(\mathrm{p}<0.05)$ increased in unilateral nephrectomized DOCA-salt hypertensive rats as compared to sham control rats. The heart rate, basal arterial blood pressure, and pressor responses to NA, Adr, PE, 5-HT, and AngII were not altered in case of PGJ (100 and $300 \mathrm{mg} / \mathrm{kg} /$ day, p.o., for 4 weeks) treated unilateral nephrectomized rats as compared to sham control rats. The heart rate, basal arterial blood pressure, and pressor responses to NA, Adr, PE, 5-HT, and AngII were significantly $(\mathrm{p}<0.05)$ reduced in case of unilateral nephrectomized DOCA-salt hypertensive rats that received PGJ (100 and $300 \mathrm{mg} / \mathrm{kg} /$ day, p.o., for 4 weeks) as compared to unilateral nephrectomized DOCA-salt hypertensive rats. It is clear from our study that PGJ has affected catecholamineinduced vasoconstriction as well as changes in heart rate in unilateral nephrectomized DOCA-salt hypertensive rats. As described earlier by Waghulde et al [19]. (1993), reduction in vascular reactivity to various agonists by PGJ (100 and $300 \mathrm{mg} / \mathrm{kg} /$ day, p.o., for 4 weeks) in DOCAsalt hypertensive rats suggests that there may be an alteration in the sensitivity of the adrenoceptors to NA, Adr, PE, 5-HT, and AngII.

OS which occurs when there is an imbalance between the generation of ROS and the antioxidant defense systems is believed to be one of most important etiological factor in hypertension. In vascular system superoxide and hydrogen peroxide are particularly important network of antioxidant enzymes. The enzyme such as SOD, CAT, and GSH is an important antioxidant defense in nearly all cells exposed to oxygen which acts through different mechanisms [20].

Pomegranate juice contains anthocyanins [21]; glucose, ascorbic acid [22]; ellagic acid, gallic acid, caffeic acid [23]; catechin, EGCG [24]; and quercetin, rutin [25] of which ellagic acid exhibits powerful antioxidant effect. Nevertheless some studies have confirmed the synergistic action of several pomegranate constituents is superior to ellagic acid. An in vitro assay using four separate testing methods demonstrated pomegranate juice and seed extracts have 2-3 times the antioxidant capacity of either red wine or green tea [26]. Pomegranate is rich in antioxidant of polyphenolic class which includes tannins and anthocyanins [27] and flavonoids [28]. Flavonoids produce endothelium dependent [29] and independent vasorelaxant effects in different blood vessels including the rat thoracic aorta [30] and inhibit lipid peroxidation [31]. As pomegranate juice which is rich in flavonoids strongly inhibit the synthesis of ET-1 (which increases oxidative stress by activation of NADPH oxidase), it is quite possible that PGJ possessing antioxidant properties, may also act by antagonizing ET-1 receptors. Evidence from this study also indicates that the level of the antioxidant enzymes of SOD, CAT, and GSH enzymes were significantly $(\mathrm{p}<0.05)$ decreased and those of TBARS were significantly $(p<0.05)$ increased in heart tissue of unilateral nephrectomized DOCA-salt hypertensive rats when compared to sham control rats. The antioxidant levels SOD, CAT, GSH enzymes, and TBARS were not altered in case of PGJ (100 and $300 \mathrm{mg} / \mathrm{kg} /$ day, p.o.) treated unilateral nephrectomized rats as compared to sham control rats. The levels of antioxidant enzymes - SOD, CAT, and GSH were significantly $(\mathrm{p}<0.05)$ increased and those of TBARS were significantly $(\mathrm{p}<0.05)$ decreased in heart

Table 3: Mean change in blood pressure to adrenaline ( $1 \mu \mathrm{g} / \mathrm{kg})$, noradrenaline $(1 \mu \mathrm{g} / \mathrm{kg})$, phenylephrine $(1 \mu \mathrm{g} / \mathrm{kg})$, angiotensin II $(25 \mathrm{ng} / \mathrm{kg})$, and 5-hydroxy tryptamine $(1 \mu \mathrm{g} / \mathrm{kg})$ in DOCA-salt hypertensive rats

\begin{tabular}{|c|c|c|c|c|c|c|}
\hline Treatment & Sham Control & PGJ 100 & PGJ 300 & DOCA & DOCA+PGJ 100 & DOCA+PGJ 300 \\
\hline Adrenaline $(1 \mu \mathrm{g} / \mathrm{kg})$ & $12.99 \pm 0.56$ & $14.25 \pm 1.47$ & $15.7 \pm 2.04$ & $24.7 \pm 1.63^{*}$ & $18.34 \pm 1.29^{\#}$ & $12.9 \pm 2.25^{\#}$ \\
\hline Noradrenaline $(1 \mu \mathrm{g} / \mathrm{kg})$ & $14.25 \pm 1.25$ & $16.49 \pm 1.76$ & $18.5 \pm 1.16$ & $25.9 \pm 1.86^{*}$ & $19.2 \pm 1.32^{\#}$ & $13.23 \pm 1.91^{\#}$ \\
\hline Phenylephrine (1 $\mu \mathrm{g} / \mathrm{kg})$ & $15.69 \pm 1.34$ & $14.35 \pm 1.03$ & $14.5 \pm 1.06$ & $25.5 \pm 2.19 *$ & $16.53 \pm 1.53^{\#}$ & $13.46 \pm 1.41^{\#}$ \\
\hline Angiotensin II (25 ng/kg) & $8.6 \pm 1.32$ & $8.55 \pm 1.53$ & $9.10 \pm 0.72$ & $25.3 \pm 1.0 *$ & $13.18 \pm 1.02^{\#}$ & $9.45 \pm 0.62^{\#}$ \\
\hline 5-hydroxy tryptamine $(1 \mu \mathrm{g} / \mathrm{kg})$ & $7.39 \pm 1.07$ & $7.80 \pm 1.07$ & $7.40 \pm 1.28$ & $10.90 \pm 0.89 *$ & $4.87 \pm 0.89^{\#}$ & $2.99 \pm 0.59^{\#}$ \\
\hline
\end{tabular}

All values are expressed as mean \pm SEM, $n=5$. All data are subjected to one-way ANOVA followed by Dunnett's test. * $<<0.05$ when compared to sham control and $\#$ p $<0.05$ when compared to DOCA group. DOCA: Deoxycorticosterone acetate, SEM: Standard error of the mean, PGJ: Punica granatum juice extract 
Table 4: Effect of Punica granatum juice extract (100, $300 \mathrm{mg} / \mathrm{kg} / \mathrm{day}$, p.o., for 4 weeks) on urinary sodium excretion in DoCA-salt hypertensive rats

\begin{tabular}{llll}
\hline \multirow{2}{*}{ Treatment groups (mg/kg) } & \multicolumn{2}{l}{ Urinary Na+excretion mMol/ml (mean \pm SEM) } \\
\cline { 2 - 4 } & I week & II week & III week \\
\hline Sham control & $0.191 \pm 0.01$ & $0.38 \pm 0.01$ & $0.34 \pm 0.07$ \\
Punica granatum (100) & $0.221 \pm 0.04$ & $0.249 \pm 0.08$ & $0.187 \pm 0.07$ \\
Punica granatum (300) & $0.185 \pm 0.04$ & $0.539 \pm 0.08^{*}$ & $0.118 \pm 0.01$ \\
DOCA (25) & $0.105 \pm 0.01$ & $0.115 \pm 0.02^{*}$ & $0.043 \pm 0.02^{*}$ \\
DOCA (25) + Punica granatum (100) & $0.214 \pm 0.04$ & $0.167 \pm 0.07$ & $0.072 \pm \pm 0.05$ \\
DOCA (25) + Punica granatum (300) & $0.238 \pm 0.08$ & $0.34 \pm 0.06$ & $0.058 \pm 0.01$ \\
\hline
\end{tabular}

Values are expressed as mean \pm SEM, $n=5$. All data are subjected to one-way ANOVA followed by Dunnett's test. ${ }^{\mathrm{p}}<0.05$ when compared to sham control and \#p $<0.05$ when compared to DOCA group. DOCA: Deoxycorticosterone acetate, SEM: Standard error of the mean

Table 5: Effect of Punica granatum juice extract on urinary potassium excretion in DoCA-salt hypertensive rats

\begin{tabular}{|c|c|c|c|c|}
\hline \multirow[t]{2}{*}{ Treatment groups (mg/kg) } & \multicolumn{4}{|c|}{ Urinary K+excretion $\mathrm{mMol} / \mathrm{ml}($ mean \pm SEM) } \\
\hline & I week & II week & III week & IV week \\
\hline Sham control & $0.078 \pm 0.017$ & $0.149 \pm 0.012$ & $0.139 \pm 0.07$ & $0.20 \pm 0.01$ \\
\hline Punica granatum (300) & $0.192 \pm 0.0297$ & $0.059 \pm 0.07$ & $0.128 \pm 0.015$ & $0.237 \pm 0.015^{*}$ \\
\hline DOCA (25) & $0.76 \pm 0.123^{*}$ & $0.28 \pm 0.014$ & $0.024 \pm 0.005^{*}$ & $0.029 \pm 0.016^{*}$ \\
\hline DOCA (25) + Punica granatum (100) & $0.358 \pm 0.081^{\#}$ & $0.126 \pm 0.043$ & $0.128 \pm 0.01$ & $0.12 \pm 0.012^{\#}$ \\
\hline DOCA (25) + Punica granatum (300) & $0.178 \pm 0.043^{\#}$ & $0.097 \pm 0.026^{\#}$ & $0.148 \pm 0.01^{\#}$ & $0.182 \pm 0.005^{\#}$ \\
\hline
\end{tabular}

Values are expressed as mean \pm SEM, $\mathrm{n}=5$. All data are subjected to one-way ANOVA followed by Dunnett's test. ${ }^{*} \mathrm{p}<0.05$ when compared to sham control and ${ }^{\#} \mathrm{p}<0.05$ when compared to DOCA group. DOCA: Deoxycorticosterone acetate, SEM: Standard error of the mean

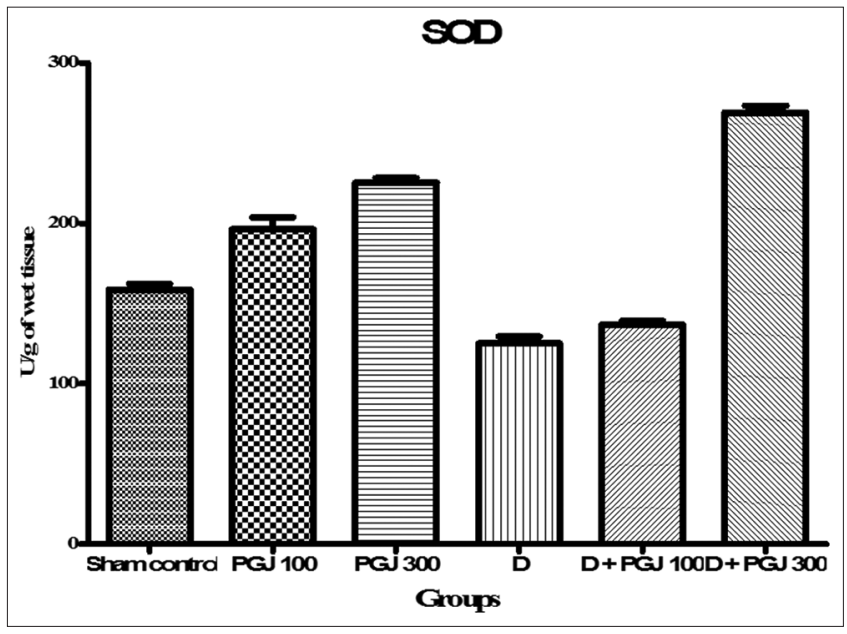

Fig. 2: Effect of PGJ (100 and $300 \mathrm{mg} / \mathrm{kg} / \mathrm{day}$, p.o., for 4 weeks) on superoxide dismutase antioxidant enzyme in DOCA-salt hypertensive rats. All values are expressed as mean $\pm S E M, n=5$. All data are subjected to one-way ANOVA followed by Dunnett's test. ${ }^{*} \mathbf{p}<0.05$ when compared to sham control and ${ }^{\#} \mathbf{p}<0.05$ when compared to DOCA group. Vertical lines represent SEM.

PGJ: Punica granatum juice extract, DOCA: Deoxycorticosterone acetate, SEM: Standard error of the mean

tissue of unilateral nephrectomized DOCA-salt hypertensive rats that received PGJ (100 and $300 \mathrm{mg} / \mathrm{kg} /$ day, p.o.) for 4 weeks as compared to unilateral nephrectomized DOCA-salt hypertensive rats. This suggests that oxidative stress developed during DOCA-salt induced hypertension has been prevented by concurrent administration of PGJ (100 and $300 \mathrm{mg} / \mathrm{kg} /$ day, p.o., for 4 weeks).

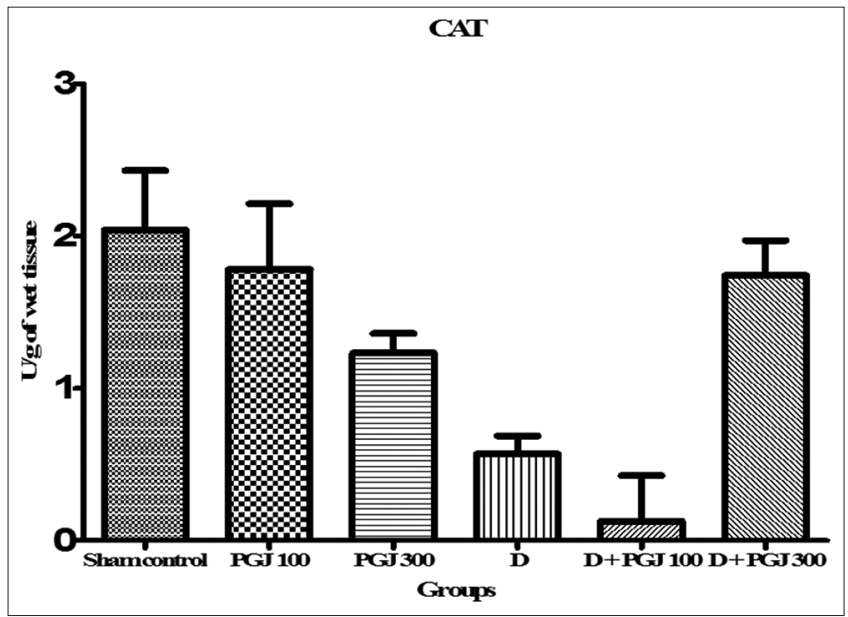

Fig. 3: Effect of PGJ (100 and $300 \mathrm{mg} / \mathrm{kg} /$ day, p.o., for 4 weeks) on catalase antioxidant enzyme in DOCA-salt hypertensive rats. All values are expressed as mean $\pm S E M, n=5$. All data are subjected

to one-way ANOVA followed by Dunnett's test. * $\mathbf{p}<0.05$ when compared to sham control and ${ }^{\#} \mathbf{p}<0.05$ when compared to DOCA group. Vertical lines represent SEM. PGJ: Punica granatum juice extract, DOCA: Deoxycorticosterone acetate, SEM: Standard error of the mean

\section{CONCLUSION}

The present work demonstrates that PGJ has an antihypertensive action in unilateral nephrectomized DOCA-salt hypertensive rats and could be possible starting point for treatment of hypertension with increased patient adherence. 


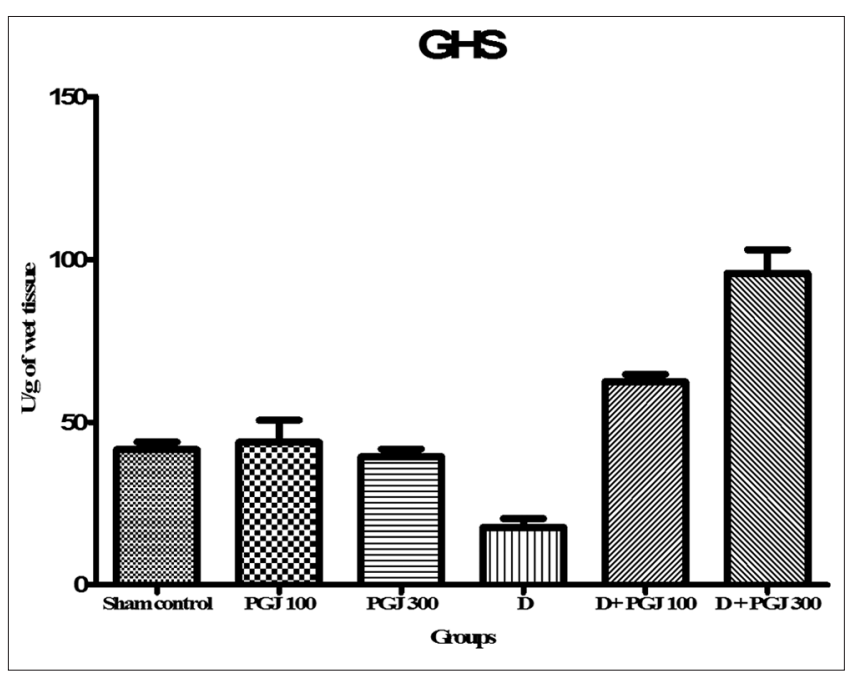

Fig. 4: Effect of PGJ (100 and $300 \mathrm{mg} / \mathrm{kg} /$ day, p.o., for 4 weeks) on reduced glutathione antioxidant enzyme in DOCA-salt hypertensive rats. All values are expressed as mean $\pm S E M, n=5$. All data are subjected to one-way ANOVA followed by Dunnett's test. ${ }^{*} \mathbf{p}<0.05$ when compared to sham control and ${ }^{\#} \mathbf{p}<0.05$ when compared to DOCA group. Vertical lines represent SEM.

PGJ: Punica granatum juice extract, DOCA: Deoxycorticosterone acetate, SEM: Standard error of the mean

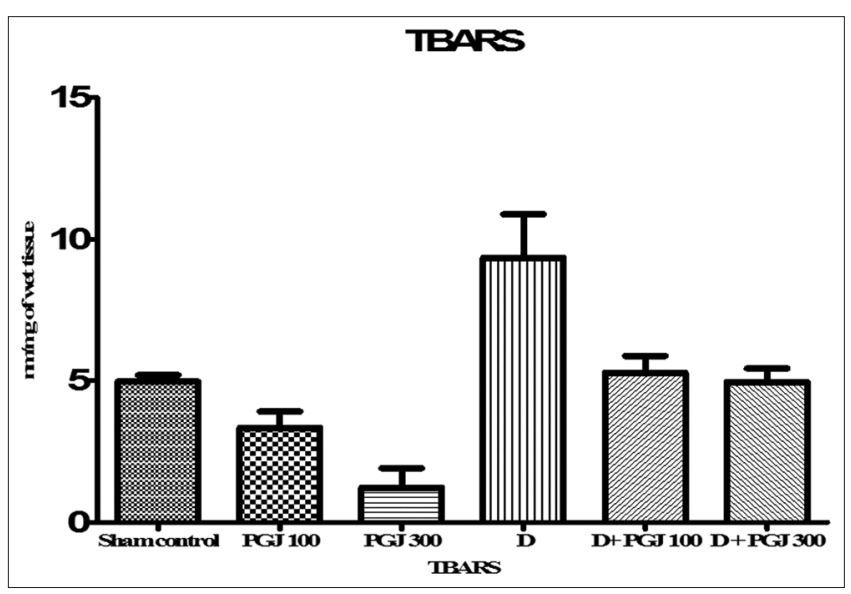

Fig. 5: Effect of PGJ (100 and $300 \mathrm{mg} / \mathrm{kg} /$ day, p.o., for 4 weeks) on TBARS values in DOCA-salt hypertensive rats. All values are expressed as mean $\pm S E M, n=5$. All data are subjected to one-way ANOVA followed by Dunnett's test. ${ }^{*} \mathbf{p}<0.05$ when compared to sham control and ${ }^{\#} \mathbf{p}<0.05$ when compared to DOCA group. Vertical lines represent SEM. PGJ: Punica granatum juice extract, DOCA: Deoxycorticosterone acetate, SEM: Standard error of the mean, TBARS: Thiobarbituric acid reactive substances

\section{AUTHOR'S CONTRIBUTION}

Conception and design, and/or acquisition of data, and/or analysis and interpretation of data: Chaudhari Pankaj M, Baviskar Dheeraj T. Drafting the article or revising: Chaudhari Pankaj M, Mahajan Sachin N.

\section{CONFLICTS OF INTEREST}

None declared.

\section{REFERENCES}

1. Kearney PM, Whelton M, Reynolds K, Muntner P, Whelton PK, He J. Global burden of hypertension: Analysis of worldwide data. Lancet
2005;365:217-23.

2. Naderi SH, Bestwick JP, Wald DS. Adherence to drugs that prevent cardiovascular disease: Meta-analysis on 376,162 patients. Am J Med 2012:125:882-70

3. Nasution A, Khairunnisa, Tanjung HR. Impacts of counseling on adherence to prescribed medications and blood pressure of hypertensive patients in four Indonesian primary health centers. Int J Pharm Pharm Sci 2015;7:114-7.

4. Jurenka J. Therapeutic application of pomegranate a review. Altern Med Rev 2008;13:128-44

5. Hamza RZ, Abd El-azez AM, Hussien NA. Evaluation of the antioxidant potential for different extracts of Al-Taif pomegranate (Punica granatum $\mathrm{L}$ ) induced by atrazine and malathion pesticides in liver of male albino mice. Int J Pharm Pharm Sci 2014;7:89-94.

6. Seyle $\mathrm{H}$, Bois P. The hormonal production of nephrosclerosis and periarteritis nodosa in the primate. Br Med J 1957;1:183-6.

7. Wolfgand VH, editors. Drug Discovery and Evaluation-pharmacological Assays. $2^{\text {nd }}$ ed. Germany: Springer Publication; 1997. p. 122-4.

8. Saggu H, Cooksey J, Dexter D. A selective increase in particulate Superoxide dismutase activity in Parkinsonin subtansia Nigra. J Neurochem 1989;53:692-7.

9. Misra HP, Fridovich I. The generation of superoxide radical during the autoxidation of hemoglobin. J Biol Chem 1972;247:6960-2.

10. Beers RF Jr., Sizer IW. A spectrophotometric method for measuring the breakdown of hydrogen peroxide by catalase. J Biol Chem 1952;195:133-40.

11. Ellman GL. Tissue sulphydryl groups. Arch Biochem Biophys 1959;82:70-7

12. Niehaus WG Jr., Samuelsson B. Formation of malonaldehyde from phospholipid arachidonate during microsomal lipid peroxidation. Eur J Biochem 1968;6:126-30.

13. Katholi RE, Naftilan AJ, Oparil S. Importance of renal sympathetic tone in the development of DOCA-salt hypertension in the rat. Hypertension 1980;2:266-73

14. National High Blood Pressure Education Program. The $7^{\text {th }}$ Report of the Joint National Committee on Prevention, Detection, Evaluation, and Treatment of High Blood Pressure. Bethesda (MD): National Heart, Lung, and Blood Institute (US); 2004.

15. Tabassum N, Ahmad F. Role of natural herbs in the treatment of hypertension. Pharmacog Rev 2011:5:30-40.

16. Kaonu O, Emmanuel LB, Robert CT. Sodium, extracellular fluid volume and calcium output changes in the genesis of mineralocorticoid hypertension in the intact dog. Hypertension 1979;1:331-6.

17. Ross EJ. The control of aldosterone secretion. In: Aldosterone and Aldesteronism. London: Lloyd Luke Ltd.; 1975. p. 144-91.

18. Tan SY, Mulrow PJ. Role of potassium in hypertension. In: Genest J, Kuchel O, Hamet P, Cantin M, editors. Hypertension. New York: Mc Graw Hill Book Company; 1983. p. 427-40.

19. Harshal W, Mahalaxmi M, Sanjay K, Balaraman R. Punica granatum attenuates angiotensin-II induced hypertension in wistar rats. Int $\mathrm{J}$ PharmTech Res 2010;2:60-7.

20. Baradaran A, Nasri H, Rafieian-Kopaei M. Oxidative stress and hypertension: Possibility of hypertension therapy with antioxidants. J Res Med Sci 2014;19:358-67.

21. Du CT, Wang PL, Francis FJ. Anthocyanins of pomegranate, Punica granatum. J Food Sci 1975;40:417-8.

22. Available from: http://www.nutritiondata.com/facts-C00001-01c20Ws. $\mathrm{html.Nutrition} \mathrm{data} \mathrm{for} \mathrm{pomegranate.} \mathrm{[Last} \mathrm{accessed} \mathrm{on} 2008$ Jan 10].

23. Amakura Y, Okada M, Tsuji S, Tonogai Y. Determination of phenolic acids in fruit juices by isocratic column liquid chromatography. J Chromatogr A 2000;891:183-8.

24. de Pascual-Teresa S, Santos-Buelga C, Rivas-Gonzalo JC. Quantitative analysis of flavan-3-ols in Spanish foodstuffs and beverages. J Agric Food Chem 2000;48:5331-7.

25. Artik N. Determination of phenolic compounds in pomegranate juice by using HPLC. Fruit Proc 1998:8:492-9.

26. Gilani AH, Aftab K, Saeed SA, Suria A. Effect of harmalol on blood pressure in anaesthetized rats. Biochem Soc Trans 1992;20:359S.

27. Nigris F, Balestrieri ML, Ignarro SW, D'Armiento FP, Fiorita C, Ignarro LJ, et al. The influence of pomegranate fruit extract in comparison to regular pomegranate juice and seed oil on nitric oxide and arterial function in obese Zucker rats. Nitric Oxide 2007; 17:50-4

28. Sudheesh S, Vijayalakshmi NR. Flavonoids from Punica granatumpotential antiperoxidative agents. Fitoterapia 2005;76:181-6. 
29. Gil MI, Tomás-Barberán FA, Hess-Pierce B, Holcroft DM, Kader AA. Antioxidant activity of pomegranate juice and its relationship with phenolic composition and processing. J Agric Food Chem 2000;48:4581-9.

30. Duarte J, Rez-Vizcaino FP, Utrilla PP, Nez JJ, Tamargo J, Zarzuelo A.
Vasodilatory effects of flavonoids in rat aortic smooth muscle. Structure-activity relationships. Gen Pharmacol 1993;24:857-62.

31. Cook NC, Samman S. Flavonoids. Chemistry, metabolism, cardioprotective effects and dietary sources. J Nutri Biochem 1996;6:66-77. 